\title{
Kalibrator Suhu dengan Thermocouple Dilengkapi Tampilan Grafik
}

\author{
Olivia Ratna Yunita\#, Dyah Titisari, Torib Hamzah \\ Jurusan Teknologi Elektro-medis Poltekkes Kemenkes, Surabaya \\ Jl. Pucang Jajar Timur No. 10, Surabaya, 60245, Indonesia \\ \#oliviaratna510@gmail.com,ti2_sari@yahoo.com, toribhamzah@yahoo.com
}

\begin{tabular}{c} 
Info Artikel \\
\hline Penerimaan Artikel
\end{tabular}

Diterima 9 Maret 2019

Revisi 15 Des 2020

Terbit 18 Des 2020

Kata kunci:

Sterilisasi

Suhu

Thermocouple

Wireless

$P L X-D A Q$

\section{Abstrak}

Sterilisator yang sering dioperasikan maupun pada penggunaan sterilisator yang tidak sesuai dengan prosedur dikhawatirkan akan menyebabkan penurunan kinerja alat yang nantinya akan berpengaruh dalam pendistribusian suhu dan menyebabkan gangguan siklus suhu saat proses sterilisasi berlangsung. Untuk itu perlu dilakukan pemantauan proses sterilisasi dengan dilakukan kalibrasi suhu menggunakan thermocouple. Penelitian ini bertujuan untuk mengembangkan alat kalibrator suhu dilengkapi tampilan grafik secara realtime pada komputer untuk memudahkan pemantauan siklus suhu. Kontribusi penelitian ini adalah saat dilakukan pengukuran suhu dengan sensor thermocouple sistem dapat melakukan plotting data pembacaan secara reatime dalam bentuk grafik. Agar dapat mengetahui keseragaman pendistribusian suhu sensor thermocouple diletakkan pada titik yang ditentukan dan dilakukan pemantauan secara grafik pada komputer untuk memantau siklus suhu secara realtime. Alat yang peneliti buat menggunakan sensor thermocouple tipe-K untuk membaca suhu, kemudian data diproses dengan minimum system ATMega328 untuk ditampilkan pada LCD karakter 4x20 dan dikirim ke komputer secara wireless melalui Bluetooth HC-05. Data yang diterima akan diintegrasikan ke spreadsheet Excel dengan aplikasi PLX-DAQ untuk diolah menjadi grafik secara realtime. Berdasarkan hasil pembandingan pengukuran suhu antara modul dengan multimeter berparameter suhu didapatkan nilai error terkecil $0.1 \%$ pada $\mathrm{T} 4$ saat pengukuran suhu uap air $\left(100^{\circ} \mathrm{C}\right)$ dan error terbesar $4 \%$ pada $\mathrm{T} 2$ dan $\mathrm{T} 3$ saat pengukuran suhu ruang $\left(30^{\circ} \mathrm{C}\right)$. Hasil penelitian ini modul dapat tampilkan grafik secara realtime pada Microsoft Excel. Hasil penelitian ini dapat diimplementasikan pada kalibrator suhu untuk memudahkan pemantauan siklus suhu sehingga dapat mengevaluasi kinerja alat.

\section{Abstract}

Sterilizers that are often operated or in the use of sterilizers that are not in accordance with the procedure are feared will cause a decrease in the performance of the tool that will be influential in the distribution of temperature and cause interference with temperature cycles during the sterilization process. Therefore, it is necessary to monitor the sterilization process with temperature calibration using a thermocouple. This research aims to develop a temperature calibrator tool featuring a real-time graphical display on the computer for easy monitoring of temperature cycles. The contribution of this research is when a temperature measurement with a thermocouple sensor system can do plotting data that real-time in graphical form. To be aware of the uniformity of the temperature distribution of thermocouple sensors is placed at the specified point and monitoring the graph on the computer to monitor the temperature cycle in realtime. The tool that researchers created uses the type-K thermocouple sensor to read the temperature, then the data is processed with a minimum of the ATMega328 system to be displayed on a $4 \times 20$ character LCD and sent to a computer wirelessly via Bluetooth HC-05. The Data received will be integrated into an Excel spreadsheet with the PLX-DAQ application to be processed into graphs in realtime. Based on the result of comparing the temperature measurement between modules with the temperature-parameter multimeter obtained the smallest error value $0.1 \%$ in T4 when measuring the temperature of water vapor $\left(100^{\circ} \mathrm{c}\right)$ and the largest error $4 \%$ in $T 2$ and $T 3$ when measuring room temperature $\left(30^{\circ} \mathrm{C}\right)$. The results of this study module can show graphs in realtime at Microsoft Excel. The results of this research can be implemented on a temperature calibrator for easy monitoring of the cycle of temperature so as to evaluate the tool performance.

\author{
Penulis korespondensi: \\ Dyah Titisati \\ Jurusan Teknologi Elektro-medis \\ Poltekkes Kemenkes, Surabaya \\ Jl. Pucang Jajar Timur No. 10, Surabaya, 60245, Indonesia \\ Email: ti2_sari@yahoo.com
}

This work is an open access article and licensed under a Creative Commons Attribution-ShareAlike 4.0 International License (CC BY-SA 4.0).

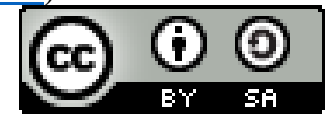

\section{Pendahuluan}

Pada sterilisator kering penggunaan udara panas kering pada sterilisasi membutuhkan waktu yang cukup lama untuk mencapai suhu sterilisasi, dan suhu yang diperlukan untuk sterilisasi lebih tinggi daripada sterilisasi dengan uap yaitu hingga suhu $170{ }^{\circ} \mathrm{C}$ [1]. Semakin tinggi suhu sterilisasi, maka akan semakin cepat proses sterilisasi. Namun dikhawatirkan akan merusak bahan atau alat yang disterilisasikan[2]. Sterilisator yang sering digunakan dalam waktu lama dengan suhu yang tinggi maupun pada penggunaan sterilisator yang tidak sesuai dengan prosedur dikhawatirkan akan menurunkan 
kinerja alat sehingga menyebabkan gangguan siklus suhu saat sterilisasi berlangsung hingga dikhawatirkan terjadi kegagalan pada proses penyeterilan[3]. Disisi lain Sterilisator kering yang masih aktif digunakan harus konsisten dan handal dalam mencapai dan mempertahankan suhu saat proses sterilisasi terjadi. Suhu yang disetting harus merata mencapai seluruh area kerja. Untuk itu perlu dilakukan pemantauan proses sterilisasi yang merupakan prosedur penilaian kualitas standar dalam pengendalian infeksi yaitu salah satunya dengan dilakukan kalibrasi suhu dengan menggunakan thermocouple[4] Thermocouple memiliki responnya yang cepat terhadap perubahaan suhu dan juga rentang suhu operasionalnya yang luas yaitu berkisar diantara $-200^{\circ} \mathrm{C}$ hingga $2000^{\circ} \mathrm{C}[5]$. Menurut panduan kalibrasi yang mengacu kepada dokumen AS 2853 1986: Enclosure-Temperature-controlled-performance testing and grading, kalibrasi dilakukan untuk mengetahui pemerataan suhu di dalam ruangan alat yang akan dikalibrasi dan sebagai acuan untuk menentukan kelayakan alat untuk tujuan pemakaian tertentu. Pengukuran suhu dilakukan pada lokasilokasi titik ukur tertentu di dalam daerah kerja (working space) sterilisator selama 1 jam atau 5 siklus terhitung setelah tercapai suhu yang stabil[6]. Untuk itu perlu dilakukan pengamatan siklus suhu secara realtime untuk memantau kinerja alat. Pemantauan siklus suhu sterilisator akan lebih mudah diamati dalam bentuk grafik dimana grafik suhu banding waktu akan memantau siklus suhu yang terjadi ketika sterilisator disetting pada suhu dan waktu tertentu pada proses sterilisasi.

Pembuatan alat kalibrator suhu dengan thermocouple telah dilakukan oleh beberapa peneliti, diantaranya: Pada tahun 2016 oleh Mochammad Sofyan dengan judul "Alat Kalibrasi Suhu dengan Thermocouple dilengkapi Thermohygrometer". Membuat alat kalibrator suhu dengan menggunakan sensor suhu berupa thermocouple dan thermohygrometer dengan menggunakan sensor SHT11 untuk mendeteksi kelembapan ruangan. Akan tetapi alat yang dibuat masih menggunakan satu sensor dan belum ada penyimpanan data [5]. Pada tahun 2017 oleh Aviliana Kusuma Bintari dengan judul "Alat Kalibrasi Suhu dengan Thermocouple dan Thermohygrometer dilengkapi Penyimpanan Data" Membuat alat kalibrator suhu dengan menggunakan sensor suhu pada media berupa thermocouple dan sensor suhu ruangan berupa LM35 serta thermohygrometer dengan menggunakan sensor DHT22 untuk mendeteksi kelembapan ruangan dilengkapi penyimpanan data menggunakan memory EEPROM. Akan tetapi alat yang dibuat masih menggunakan satu sensor dan belum dilengkapi tampilan grafik[7]. Pada tahun 2019 Syafiq Naufal Syayakti melakukan penelitian berjudul "Kalibrator Sterilisator 4 Channel". Membuat alat kalibrator suhu dengan menggunakan 4 sensor thermocouple dikhususkan untuk melakukan pengukuran pada sterilisator kering. Hasil suhu ditampilkan pada LCD $4 \times 20$ diproses oleh mikrokontroller Arduino Nano. Akan tetapi alat yang dibuat belum dilengkapi data logger dan tampilan grafik[8]. Pada tahun 2019 Aninda Zakia Febriyanti melakukan penelitian dengan judul "Kalibrator Suhu dengan Thermocouple Berbasis Mikrokontroller" Membuat alat kalibrator suhu dengan 5 chanel sensor thermocouple dengan menggunakan mikrikontroller ATMega328 sebagai pengolah data. Hasil pengukuran ditampilkan pada LCD 4x20 serta dilengkapi penyimpanan data menggunakan memory EEPROM. Akan tetapi alat yang dibuat belum dilengkapi tampilan grafik[9]. Pada tahun 2019 Rizkiyatussani melakukan penelitian dengan judul "Kalibrator Suhu (5 Channel) Menggunakan Thermocouple Dilengkapi Penyimpanan Data". Membuat alat kalibrator suhu dengan 5 chanel sensor thermocouple dilengkapi penyimpanan data pada micro SD card. Hasil suhu ditampilkan pada LCD 4x20 diproses oleh mikrokontroller Arduino Uno. Akan tetapi alat yang dibuat masih belum dilengkapi tampilan grafik[10]. Studi literatur mengenai sistem pemantauan dengan PLX-DAQ telah dibuat oleh beberapa peneliti, diantaranya: Pada tahun 2015 Muhammad Rizal Fachri,dkk melakukan penelitian dengan judul "Pemantauan Parameter Panel Surya Berbasis Arduino secara Real Time". Beliau berhasil membuat sistem pemantauan kinerja panel surya yang dirancang dilengkapi dengan sensor pengukur arus dan tegangan, dengan sistem akuisisi data yang diintegrasikan ke spreadsheet Excel menggunakan program aplikasi PLX-DAQ dan kartu memori sebagai penyimpan data cadangan. Perancangan sistem berbasis mikrokontroler Arduino Atmega 328P dan dihubungkan ke komputer melalui port serial RS232. [11]. Pada tahun 2018 Hammoumi melakukan penelitian dengan judul "Low-cost virtual instrumentation of $P V$ panel characteristics using Excel and Arduino in comparison with traditional instrumentation" dibuatlah sistem akuisisi data dengan sensor arus dan tegangan berbiaya rendah, dan data disajikan dalam Excel dengan menggunakan akuisisi data PLX-DAQ Excel Macro, yang memungkinkan komunikasi antara Mikrokontroler ATMega328 dari papan Arduino UNO dan komputer dengan bus UART. Karenanya, karakteristik I - V dan P - V, yang diproses dalam kondisi waktu nyata, dapat diperoleh secara langsung dan diplot pada lembar kerja Excel tanpa perlu memprogram ulang mikrokontroler ditemukan bahwa solusi kami hadir. Pembuatan alat ini memiliki kelebihan dibandingkan dengan cara tradisional seperti data dapat disajikan dalam bentuk grafis di waktu sebenarnya, dapat menggantikan intervensi manusia hindari kemungkinan kesalahan terkait pembacaan data dari multimeter karena lebih murah dan menghemat banyak waktu. Karena itu, sistem yang diusulkan dapat memfasilitasi asimilasi dan pencatatan data serta pembuatan dan kustomisasi laporan yang dapat dianalisis untuk ditingkatkan kinerja sistem PV. [12].

Berdasarkan uraian studi pustaka yang telah diuraikan, maka ada beberapa hal yang perlu diselesaikan melalui sebuah penelitan antara lain: 1) pembuatan kalibrator dengan satu chanel sensor hanya dapat melakukan pembacaan pada satu titik pengukuran, 2) Belum dibuat sistem pemantauan suhu secara grafik. Oleh karena itu pada penelitian ini akan dirancang sebuah alat kalibrator suhu dengan menggunakan 5 sensor thermocouple dilengkapi tampilan grafik secara realtime pada komputer (Excel) serta pengiriman data dilakukan secara wireless. Dengan tujuan untuk memudahkan pemantauan kinerja alat dalam pendistribusian suhu secara grafik pada 5 titik pengukuran. Penggunaan rancangan ini mempunyai kelebihan dalam hal: 1)Membentuk tampilan grafik akan 
memudahkan pemantauan distribusi suhu, 2) Sistem pengiriman data yang dapat diakses secara nirkabel menggunakan bluetooth. 3)Dibuat modul dengan dilengkapi 5 channel sensor thermocouple.

Artikel ini terdiri dari 5 bagian, Bagian II berisi metode dan pengembangan yang akan dilakukan, Bagian III merupakan hasil-hasil yang didapatkan pada penelitian, Bagian IV adalah pembahasan temuan-temuan, dan Bagian V adalah kesimpulan.

\section{BAHAN DAN METODE}

\section{A. Experimental Setup}

Penelitian ini menggunakan 5 sensor termokopel tipe-k dan dilakukan pengukuran suhu pada suhu ruang dan suhu uap air dengan pengambilan data sebanyak 6 kali saat suhu stabil.

\section{1) Materials and Tool}

Penelitian ini menggunakan 5 sensor termokopel tipe-k sebagai pengukur suhu. Themocouple dihubungkan dengan modul MAX6675 untuk dikonversi menjadi data digital. Rangkaian minimum system ATMega328 digunakan sebagai pengolah dengan bantuan software pemrograman Arduino (Version 1.8.5) LCD karakter 4x20 digunakan menampilkan hasil. Bluetooth HC-05 digunakan untuk pengiriman hasil data serial ke komputer. PLX-DAQ(Vesion 2) sebagai aplikasi pengintegrasi hasil data ke Microsoft Excel. Multimeter berparameter suhu digunakan sebagai pembanding sementara dengan modul alat yang dibuat.

\section{2) Experiment}

Dalam penelitian ini, peneliti menyusun modul yang dapat melakukan pengukuran suhu menggunakan sensor thermocouple tipe-k. Hasil pembacaan suhu ditampilkan pada LCD karakter dan dikirim ke komputer secara wireless dengan bluetooth $\mathrm{HC}-05$. Hasil data yang diterima komputer akan diintegrasikan pada spreadsheet Excel melalui aplikasi PLXDAQ. Peneliti membandingkan hasil pengukuran modul dengan multimeter berparameter suhu pada suhu ruangan.

\section{B. Blok Diagram Alat}

Gambar.1 merupakan gambar blok diagram alat yang berisi alur proses kerja komponen yang terjadi pada alat. Blok diagram tersebut memiliki cara kerja sebagai berikut: Ketika saklar power ditekan dalam posisi On maka seluruh rangkaian akan mendapatkan tegangan dari baterai. Pada modul ini, input didapatkan pada 5 sensor thermocouple tipe-k yang akan melakukan pembacaan suhu dihubungkan dengan modul MAX6675 untuk dilakukan penguatan tegangan dan mengubah output kedalam data digital. Kemudian data digital diinputkan pada mikrokontoller minimum system ATMega328 untuk diproses dengan suatu program. Data yang telah diproses akan ditampilkan pada LCD karakter 4x20 yang menampilkan hasil data pengukuran suhu dan data akan dikirim secara wireless dengan bluetooth $\mathrm{HC}-05$ pada PC untuk dilakukan pengolahan tampilkan data grafik.

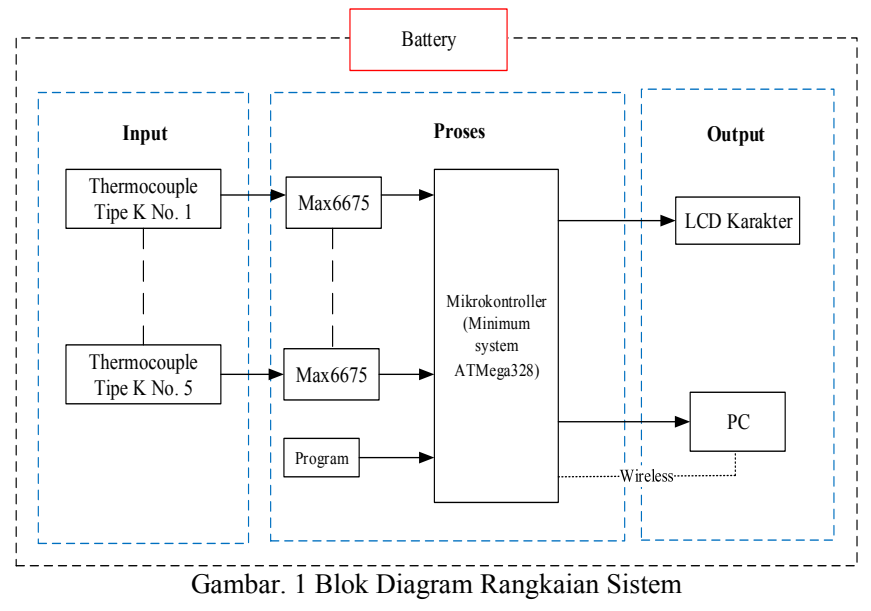

\section{Diagram Alir pada Alat}

Mekanisme kerja program Arduino pada alat didasarkan pada diagram alur seperti yang ditunjukkan pada Gambar. 2 sebagai berikut: Setelah alat dihidupkan akan dilakukan inisialisasi program pada mikrokontroller sehingga sensor thermocouple dapat melakukan pengukuran suhu. Kemudian data hasil pengukuran diproses oleh mikrokontroller yang nantinya akan ditampilkan pada LCD karakter berupa hasil pengukuran. dan dilakukan pengiriman data hasil pengukuran ke PC secara wireless dengan bluetooth $\mathrm{HC}-05$.

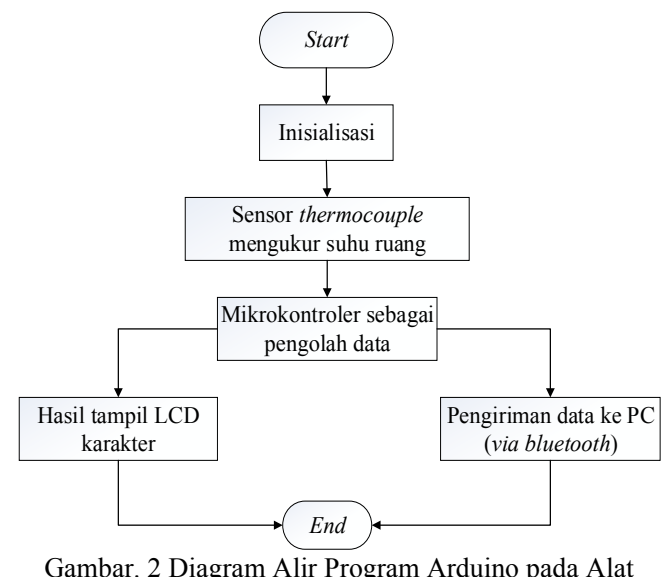

\section{Diagram Alir pada Komputer}

Mekanisme kerja penerimaan data serial pada komputer didasarkan pada diagram alur seperti yang ditunjukkan pada Gambar. 3 sebagai berikut: Setelah dilakukan inisialisasi, alat akan mengirim data pembacaan suhu melalui bluetooth ke komputer, komputer sebagai receiver perlu dihubungkan dengan bluetooth pada alat. Setelah bluetooth terhubung, buka lembar excel yang telah diaktifkan macros-nya. Kemudian connect-kan port serial bluetooth dan baudrate Arduino pada aplikasi PLX-DAQ. Setelah terkoneksi PLX-DAQ akan menerima data serial yang dikirimkan. Kemudian oleh PLXDAQ data dapat diintegrasikan pada Microsoft Office Excel sehingga data dapat ditempatkan pada spreadsheet Excel, dan kemudian data akan diolah menjadi grafik secara realtime. 


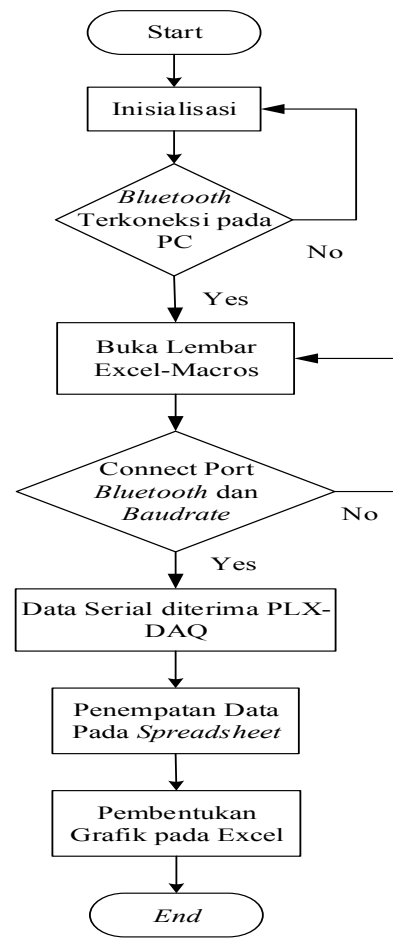

Gambar. 3 Diagram Alir Penerimaan Data Serial pada Komputer

\section{E. Rangkaian}

Bagian penting dari alat ini adalah rangkaian yang diilustrasikan pada Gambar. 5 (rangkaian gabungan MAX6675). Rangkaian beberapa modul ini digunakan untuk memproses output suhu kedalam data digital untuk diproses dengan minimum system Atmega328.

\section{1) MAX6675}

MAX6675 adalah pengkondisi sinyal yang mendapatkan masukan dari termokopel tipe $\mathrm{K}$ dan mengubah suhu menjadi data digital 12 bit[13].

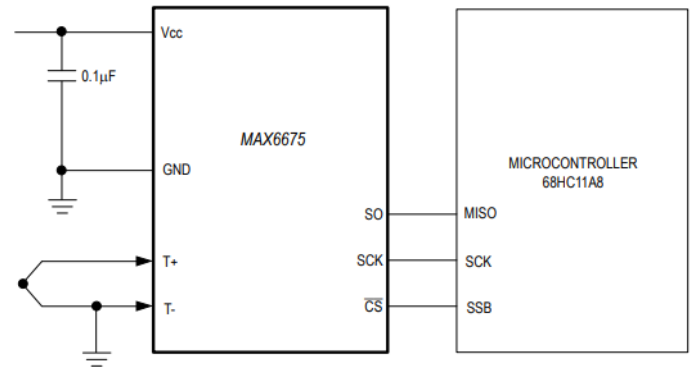

Gambar. 4 Rangkaian Pengaplikasian MAX6675 terhadap Mikrokontroller (Sumber: Maxim Integrated, "Datasheet MAX6675”[13])

Gambar. 4 merupakan rangkaian dasar dalam mengaplikasikan modul MAX6675, dimana thermocouple disambungkan sesuai polaritas sebagai input modul. Modul MAX6675 sebagai penguat yang akan mengeluarkan output berupa data digital. Pin Output MAX6675 disambungkan dengan mikrokontroller sesuai dengan Gambar. 4
Modul MAX6675 terdiri dari 5 pin yaitu sebagai berikut [13]:

SO : merupakan pin output data pembacaan sensor yang dikirimkan ke mikrokontroler.

CS : pada posisi low dan mendapatkan kiriman clock, maka modulakan melakukan pembacaan data, dan akan mengakhiri pembacaan ketika CS kembali high.

SCK : merupakan pin yang membawa informasi clock antara modul dan pengontrolnya.

VCC: pin pada modul yang tersambung dengan tegangan positif.

GND : pin pada modul yang tersambung dengan ground.

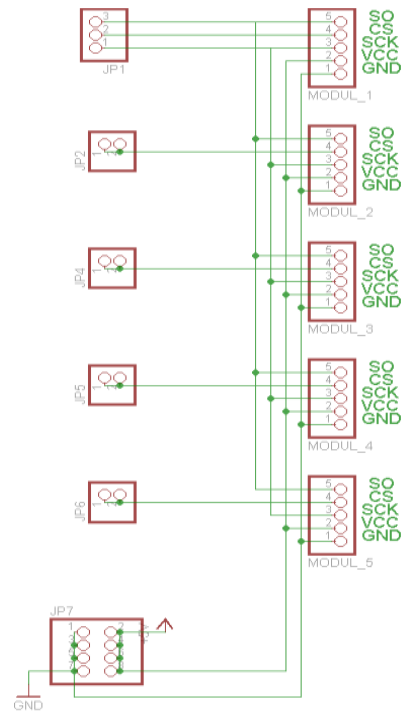

Gambar. 5 Rangkaian Gabungan Modul MAX6675 pada Alat

Pada Gambar. 5 merupakan rangkaian gabungan modul MAX6675 yang nantinya akan dihubungkan pada mikrokontroller. Terdapat pin output MAX6675 SO yang merupakan output data pembacaan dan SCK sebagai pembawa informasi clock, pada tiap modul pin sejenis di couple menjadi satu karena memiliki fungsi yang sama. Dan pin CS membantu melakukan insialisasi program hingga tiap sensor dapat melakukan pembacaan suhu sehingga pin ini di sambungkan dengan mikrokontroller menggunakan pin masing-masing.

\section{2) Bluetooth Module}

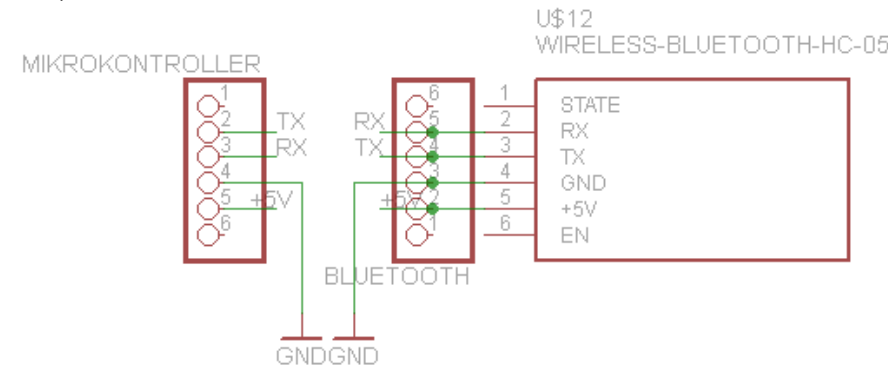

Gambar. 6 Koneksi Bluetooth HC-05 dengan Mikrokontroller 
Pada Gambar.6 modul Bluetooth yang digunakan dalam alat ini adalah Bluetooth HC-05. Modul Bluetooth digunakan untuk mengirimkan data serial hasil pembacaan suhu ke komputer. Modul Bluetooth terhubung ke mikrokontroler dengan menghubungkan pin TX mikrokontroler ke pin Bluetooth RX dan sebaliknya, pin RX mikrokontroler ke pin Bluetooth TX.

\section{3) Mikrokontroller}

Pada modul ini dibuat Minimum System ATMega328 sebagai mikrokontroller pengolah data sistem. Minimum System ini terdiri dari Kristal Oscillator (XTAL) sebagai external clock, Rangkaian RESET untuk mengatur ulang mikrokontroller dan IC ATMega328P yang telah di bootloader agar dapat dimasukkan program sistem[14].

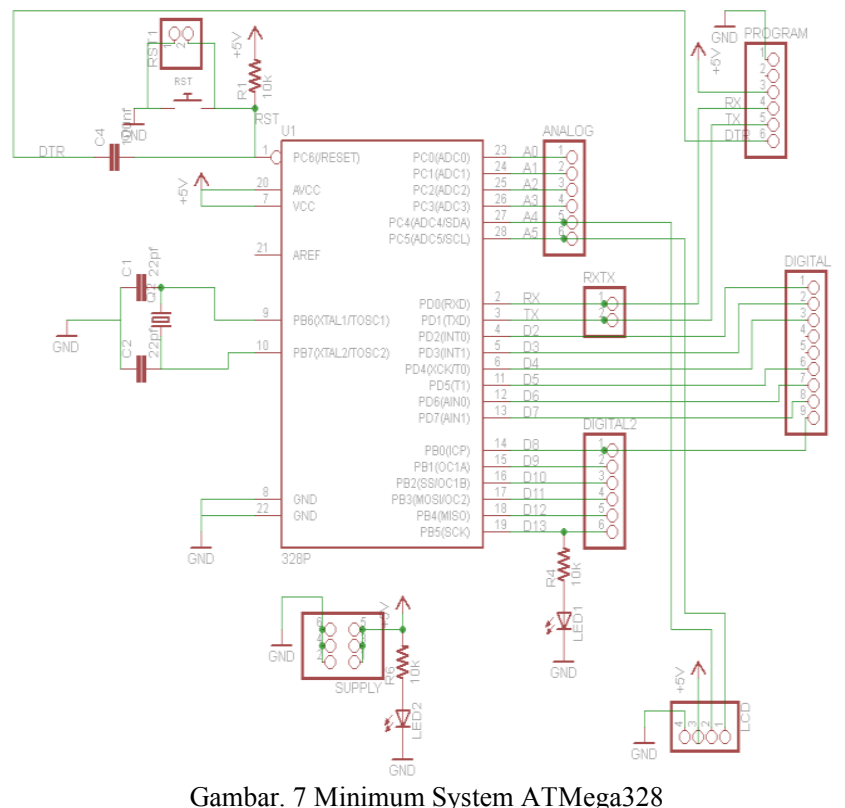

Rangkaian mikrokontroler menggunakan IC ATMega328P diperlihatkan dalam Gambar. 7 digunakan untuk memproses data keluaran dari masing-masing sensor. Serta digunakan untuk pemrograman dan transmisi data serial dengan Bluetooth. Output dari rangkaian modul MAX6675 akan dihubungkan ke pin digital 7 -13 mikrokontroller.

\section{HASIL}

Dalam penelitian ini, modul diuji dengan membaca suhu pada suhu ruang $\left(30^{\circ} \mathrm{C}\right)$ dan pada suhu uap air $\left(100^{\circ} \mathrm{C}\right)$ serta membandingkan hasilnya dengan multimeter berparameter suhu (Zotek Tipe ZT102, China) yang memiliki 1 channel sensor pengukur suhu.

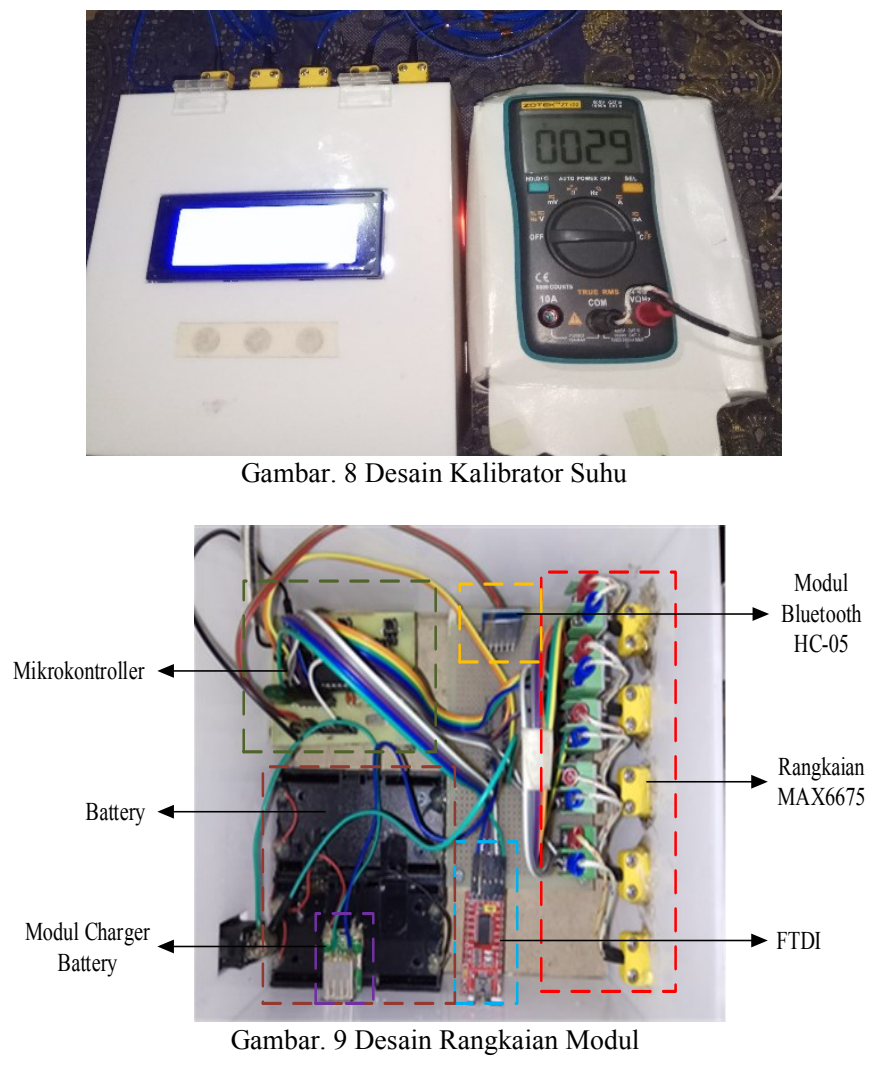

1) Desain Kalibrator Suhu

Pada Gambar. 8 merupakan desain box tampak atas saat dilakukan pengambilan data saat suhu ruang. Dapat dilihat pada alat data hasil pengukuran ditampilkan pada LCD karakter 4x20 dan alat dilengkapi dengan 5 connector sensor thermocouple.

Pada Gambar. 9 merupakan desain rangkaian modul didalam box. Pada alat kalibrator suhu ini menggunakan baterai type 18650 sebagai sumber tegangan. Baterai dapat diisi ulang dayanya menggunakan modul charger step up (modul power bank) dengan menyambungkan ke sumber tegangan DC $5 \mathrm{~V}$ melalui USB micro. Tegangan baterai yang awalnya $3,7 \mathrm{~V}$ dengan modul step up akan distabilkan dan di naikkan sebesar $5 \mathrm{~V}$ yang sesuai dengan tegangan spesifikasi kebutuhan komponen. Mikrokontroller berupa Minimum System ATMega328 digunakan untuk mengolah data hasil pengukuran suhu yang diinputkan dari modul MAX6675 Untuk mempermudahkan penguploadan program Minimum System ATMega328 dihubungkan dengan external programmer berupa FTDI USB. Alat ini juga dilengkapi bluetooth HC-05 sebagai transmitter data hasil pengukuran ke PC.

\section{2) Listing Program Pengolahan Data dengan Modul MAX6675}

Pada Listing program 1. Merupakan program pada arduino untuk mengolah hasil pembacaan suhu oleh thermocouple dengan bantuan modul MAX6675. 
Listing program 1. Program Pengolahan Data dengan Modul MAX6675

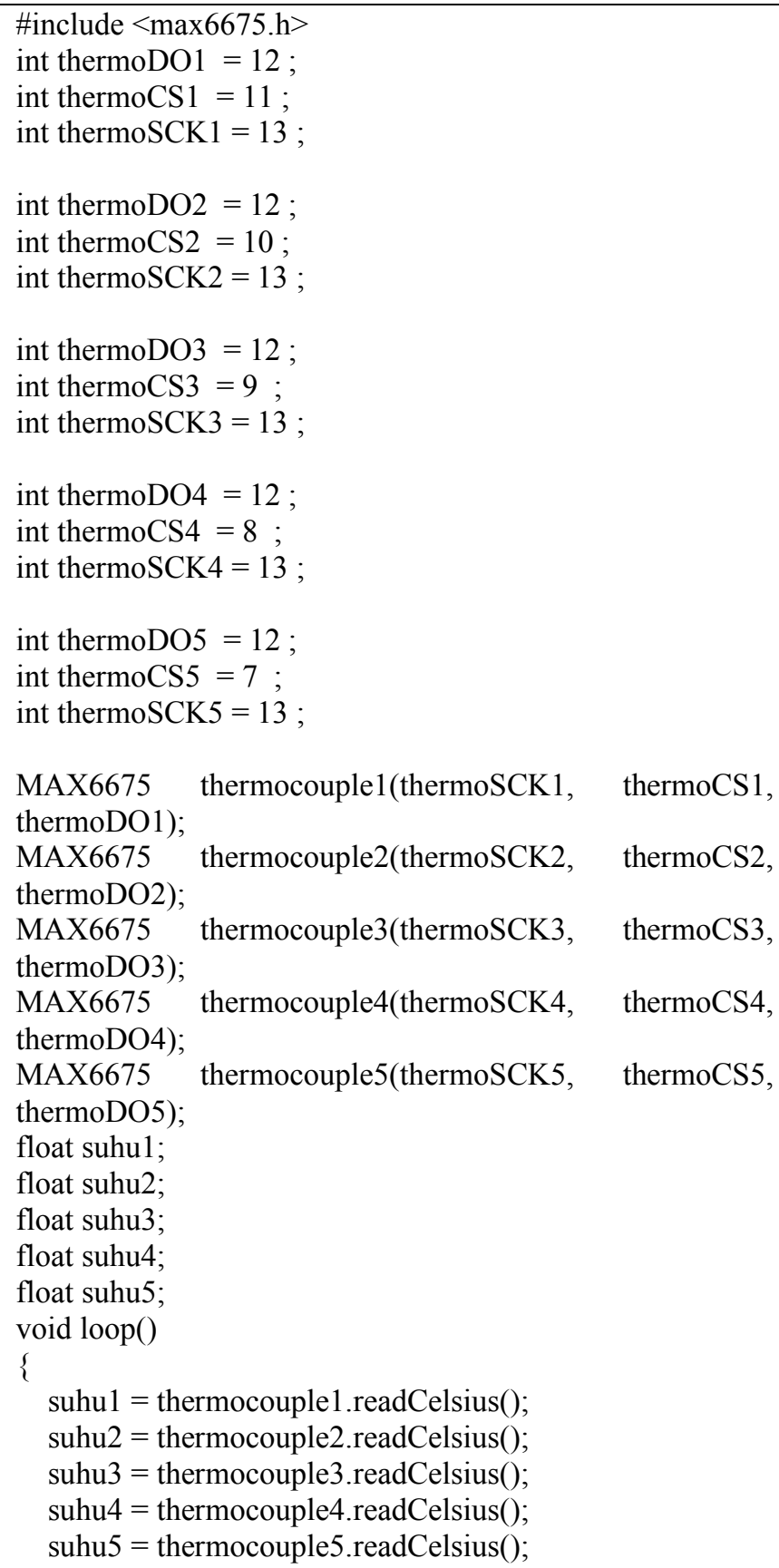

\section{3) Listing Program Tampilan LCD Karakter}

Listing Program 2. merupakan listing pemrograman untuk menampilkan hasil pengukuran pada LCD karakter, dimana LCD karakter menggunakan modul I2C.

Listing Program 2. Program Tampilan LCD Karakter \#include $<$ LiquidCrystal_I2C.h $>/ /$ library I2C LCD

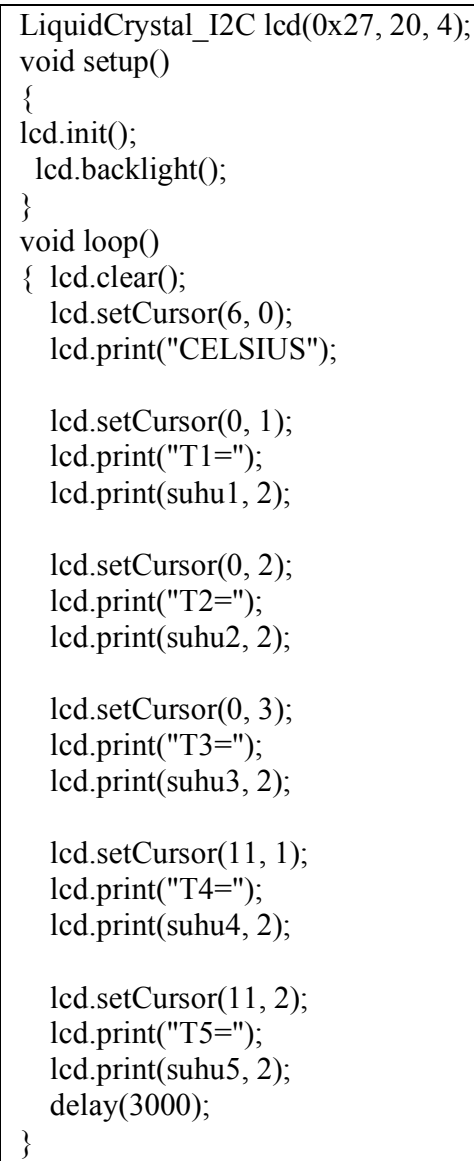

\section{4) Listing Pengiriman Data ke Komputer}

Listing Program 3. merupakan listing pemrograman pengiriman data serial ke komputer melalui komunikasi serial Bluetooth HC-05. Data serial yang masuk ke komputer akan diterima PLX-DAQ untuk di intregasikan pada Microsoft Excel.

Listing Program 3. Program Pengiriman Data ke komputer

\#include $<$ SoftwareSerial.h>
\#define rxPin 4
\#define txPin 3
SoftwareSerial bluetooth( rxPin, txPin);
void setup()
\{
-------------Program PLX DAQ-------------------
Serial.begin(115200);
bluetooth.begin(115200);
Serial.println("CLEARDATA");




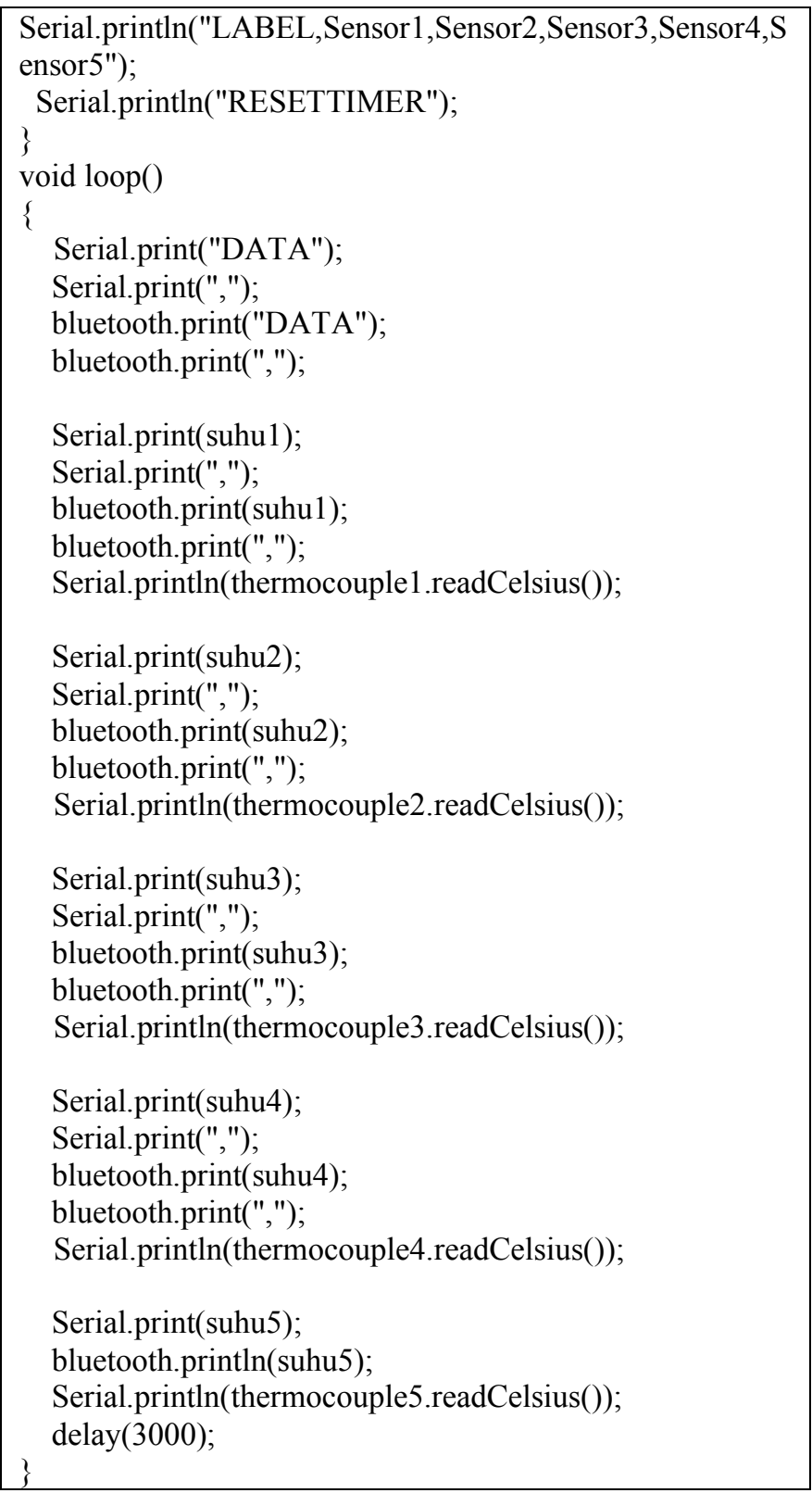

Serial.println("LABEL,Sensor1,Sensor2,Sensor3,Sensor4,S ensor5");

Serial.print("DATA");

Serial.print(",")

bluetooth.print("DATA");

bluetooth.print(suhu1);

bluetooth.print(",");

Serial.print(suhu2)

Serial.print(","),

bluetooth.print(suhu2)

bluetooth.print(",");

Serial.println(thermocouple2.readCelsius $(0)$;

print(suhu3)

Serial.print(",");

bluetooth.print(",")

Serial.print(suhu4)

Serial.print(",");

bluetooth.print(suhu4)

bluetooth.print(",");

Serial.println(thermocouple4.readCelsius $(\theta)$

Serial.println(thermocouple5.readCelsius()); delay $(3000)$

\section{5) Tampilan Data Grafik pada Microsoft Excel}

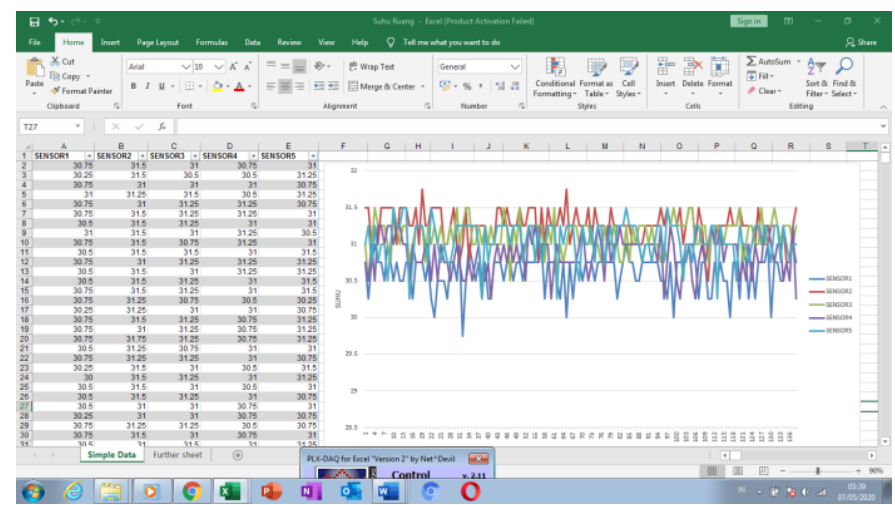

Gambar. 10 Lembar Microsoft Excel saat Pengukuran

Gambar. 10 merupakan tampilan lembar Microsoft Excel saat pengukuran berlangsung pada suhu ruangan. Sistem bekerja dengan menghubungkan komputer dengan bluetooth pada modul. Setelah tersambung buka lembar Microsoft Excel Sample yang telah dihidupkan Macros-nya, sehingga aplikasi PLX-DAQ dapat digunakan. Pada Gambar. 11 merupakan tampilan aplikasi PLX-DAQ. Setelah aplikasi muncul, masukkan port serial dan baudrate bluetooth (sesuai dengan settingan dalam program Arduino) pada aplikasi PLX-DAQ kemudian Klik tombol "conect" maka data akan masuk dalam tabel spreadsheet Excel secara realtime setiap 3 detik serta secara bersamaan dilakukan plotting data ke bentuk grafik secara realtime.
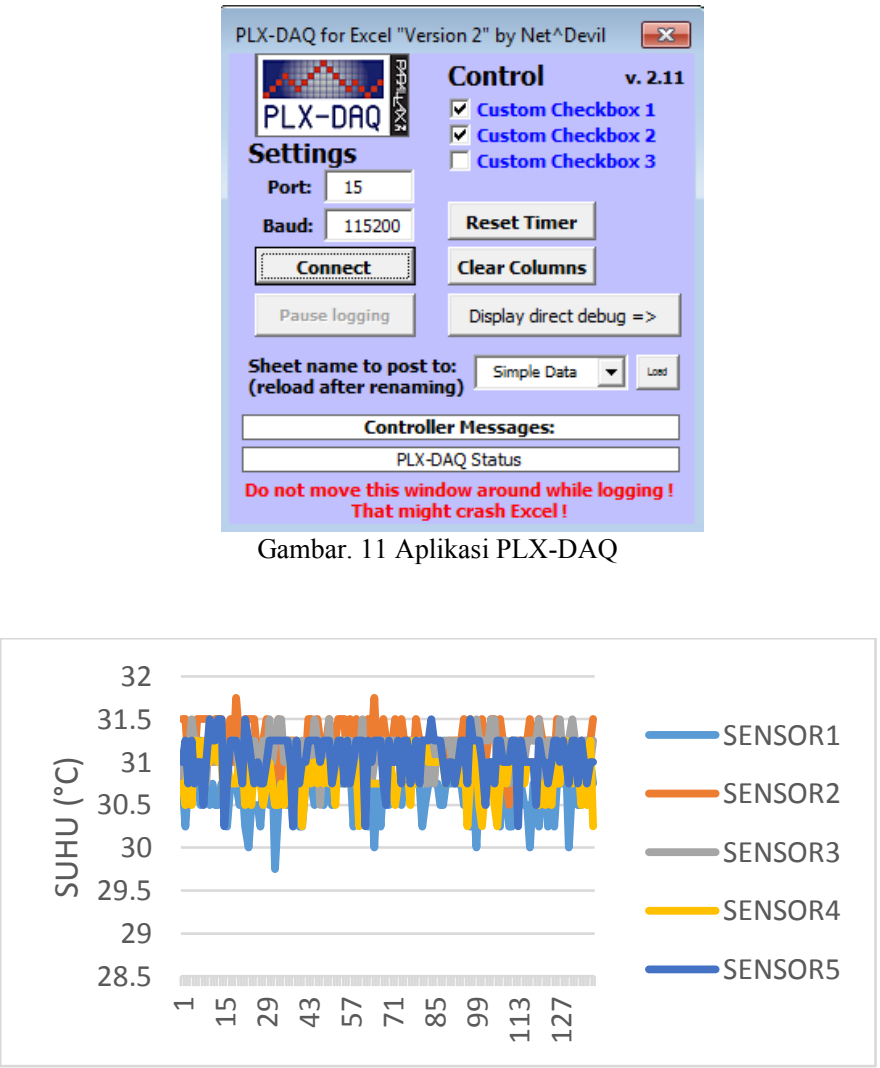

Website: Teknokes.poltekkesdepkes-sby.ac.id 
Gambar. 12 Bentuk Grafik Pemantauan saat Suhu Ruang

Pada Gambar. 12 merupakan bentuk grafik pemantauan 5 sensor thermocouple secara realtime pada suhu ruang $\left(30^{\circ} \mathrm{C}\right)$. Pada sumbu $\mathrm{Y}$ merupakan suhu yang diukur dan sumbu $\mathrm{X}$ merupakan kolom saat terjadinya pengukuran.

Dari pemantauan grafik dengan 5 sensor secara bersamaan pada suhu ruang $\left(30^{\circ} \mathrm{C}\right)$ tanpa diberikan perlakuan pada Gambar. 12, pembacaan oleh sensor pada modul yang diplotting tiap 3 detik pada Excel masih fluktuatif.

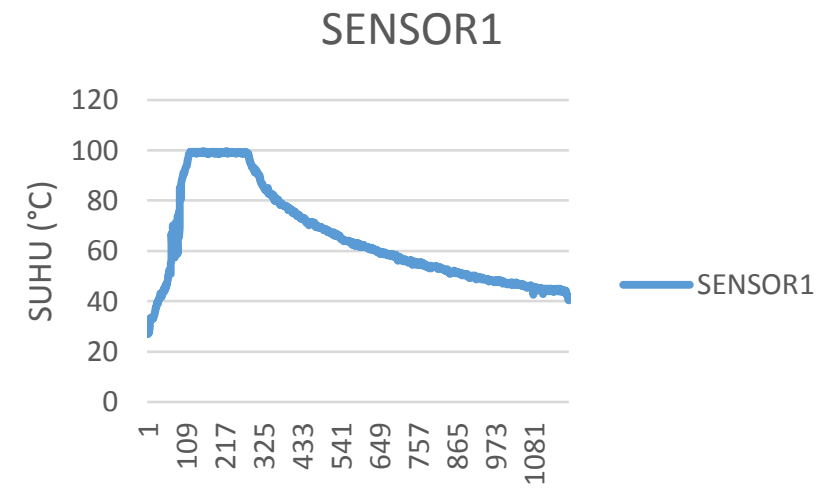

Gambar. 13 Grafik Pemantauan Sensor 1 pada Suhu Uap Air

Pada Gambar. 13 merupakan bentuk grafik pemantauan pada sensor 1 pada suhu uap air $\left(100^{\circ} \mathrm{C}\right)$. Pengukuran kali ini dilakukan satu-persatu karena alat pembanding memiliki satu sensor ukur. Dari hasil pengukuran dapat dilihat bahwa pada proses pemanasan berlangsung lebih cepat daripada pada proses pendinginan. Pada saat air mendidih sebagai simulasi proses sterilisasi suhu relatif konstan.

\section{6) Pembandingan Pembacaan Suhu Modul dengan}

Pembanding Secara Grafik

Pembandingan pembacaan suhu modul dengan pembanding ditujukan untuk mengetahui bagaimana kinerja dan kevalidan pembacaan suhu pada modul yang peneliti buat dibandingkan perangkat pembanding. Kegiatan ini dilakukan dengan melakukan pencatatan pada lembar kalibrasi secara manual yang dilakukan peneliti saat proses sterilisasi berlangsung dimana dilakukan 6 kali pencatatan setelah suhu mulai stabil.

Berikut ini dari Gambar. 14 sampai dengan Gambar. 18 merupakan hasil perbandingan pencatatan data pada suhu ruangan yang digambarkan dalam bentuk grafik.

\section{Data T1 pada Pengukuran Suhu Ruang}

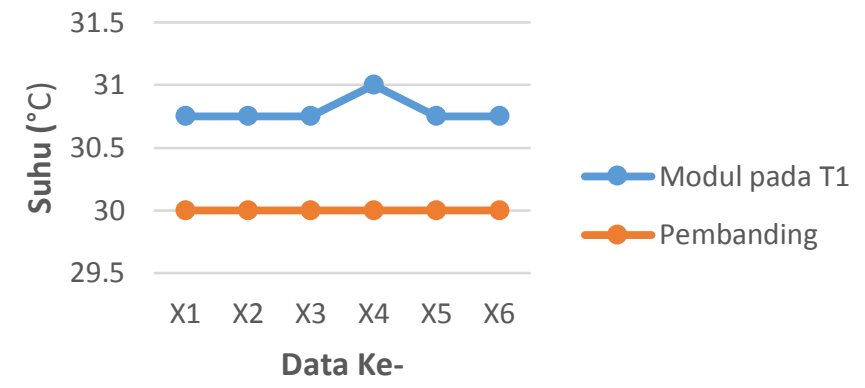

Gambar. 14 Grafik Pembandingan pada T1 saat Suhu Ruang

Data T2 pada Pengukuran Suhu Ruang

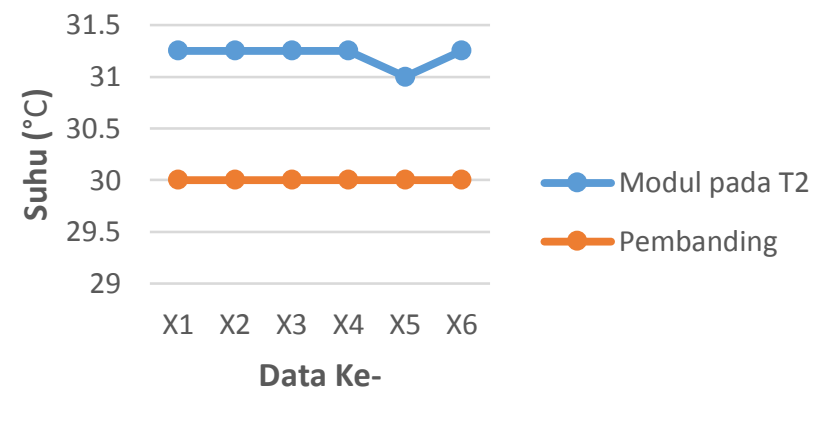

Gambar. 15 Grafik Pembandingan pada T2 saat Suhu Ruang

Data T3 pada Pengukuran Suhu Ruang

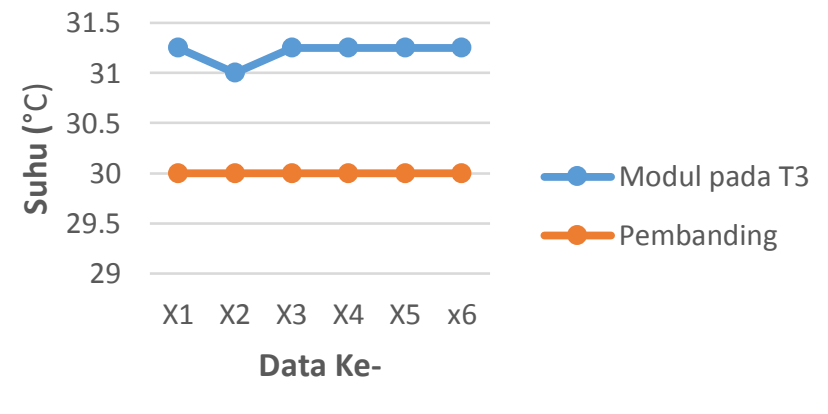

Gambar. 16 Grafik Pembandingan pada T3 saat Suhu Ruang 
Data T4 pada Pengukuran Suhu Ruang

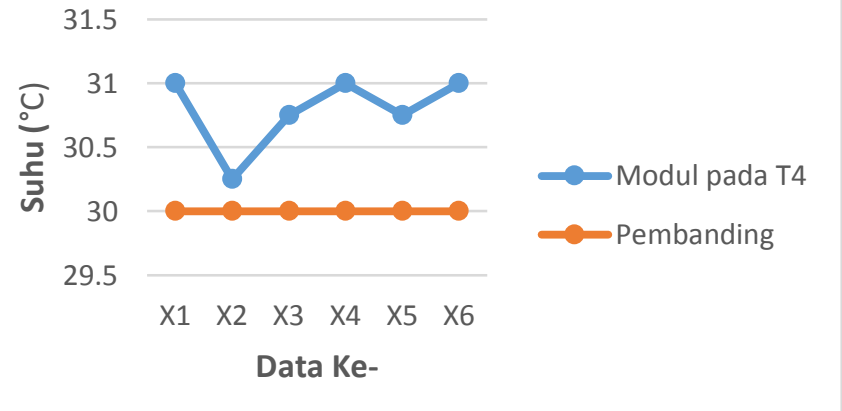

Gambar. 17 Grafik Pembandingan pada T4 saat Suhu Ruang

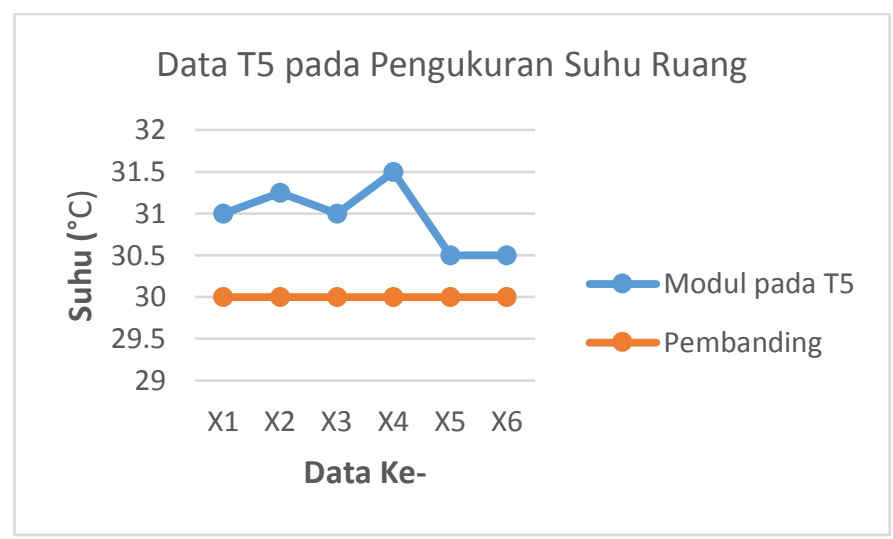

Gambar. 18 Grafik Pembandingan pada T5 saat Suhu Ruang

Dapat dilihat dari pembandingan hasil pencatatan data pada suhu ruang secara grafik pada Gambar. 14 sampai dengan Gambar. 18 hasil pembacaan suhu pada modul masih fluktuatif namun modul dapat melakukan pembacaan suhu dengan kesalahan yang tidak lebih dari standart toleransi yaitu tidak lebih dari $10 \%$.

Berikut ini dari Gambar. 19 sampai dengan Gambar. 23 merupakan hasil perbandingan pencatatan data pada suhu uap air yang digambarkan dalam bentuk grafik.
Data T1 pada Pengukuran Suhu Uap Air

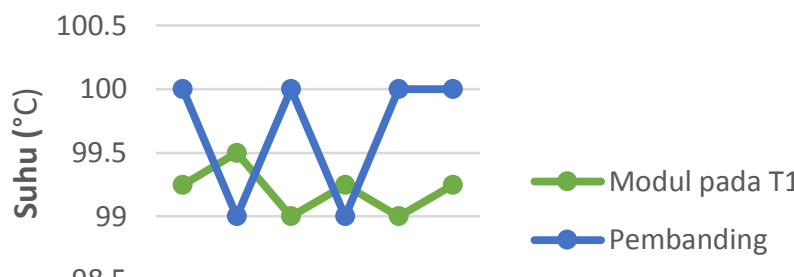

98.5

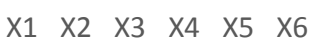

Data Ke-

Gambar. 19 Grafik Pembandingan pada T1 saat Suhu Uap Air

\section{Data T2 pada Pengukuran Suhu Uap Air}

100.5

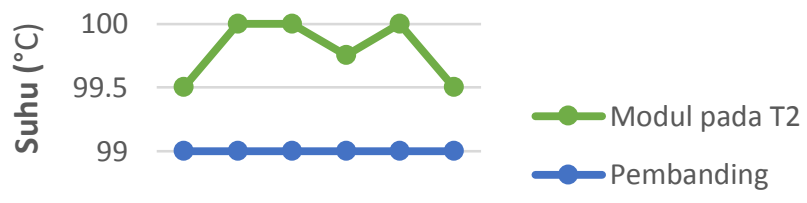

98.5

$\begin{array}{lllllll}\mathrm{X} 1 & \mathrm{X} 2 & \mathrm{X} 3 & \mathrm{X} 4 & \mathrm{X} 5 & \mathrm{X} 6\end{array}$

Data Ke-

Gambar. 20 Grafik Pembandingan pada T2 saat Suhu Uap Air

Data T3 pada Pengukuran Suhu Uap Air

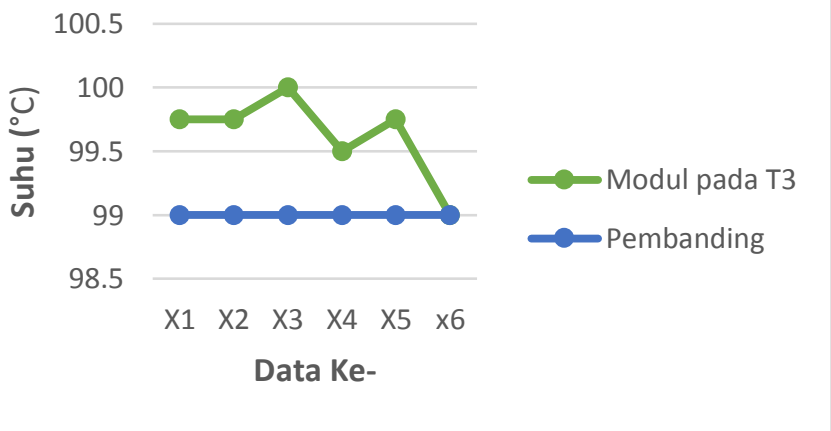

Gambar. 21 Grafik Pembandingan pada T3

Website: Teknokes.poltekkesdepkes-sby.ac.id 


\section{Data T4 pada Pengukuran Suhu Uap Air}

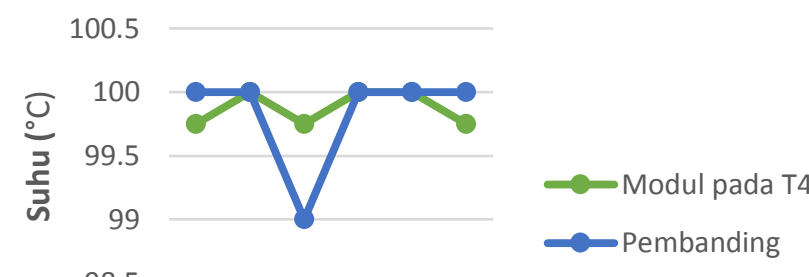

98.5

$\begin{array}{llllll}\mathrm{X} 1 & \mathrm{X} 2 & \mathrm{X} 3 & \mathrm{X} 4 & \mathrm{X} 5 & \mathrm{X} 6\end{array}$

Data Ke-

Gambar. 22 Grafik Pembandingan pada T4

\section{Data T5 pada Pengukuran Suhu Uap Air}

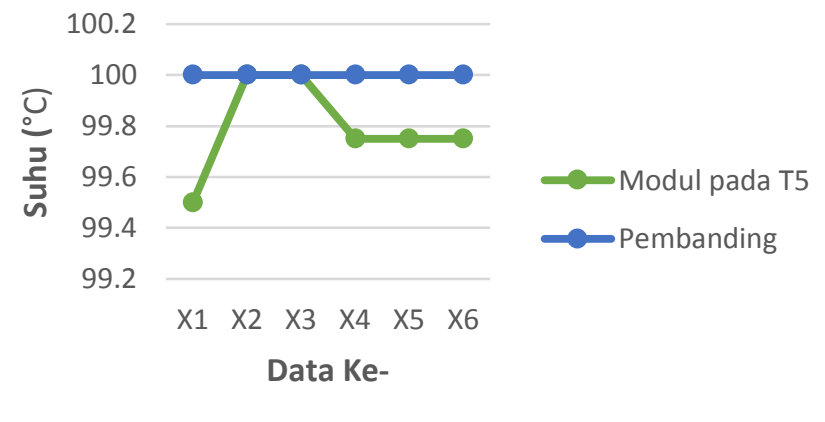

Gambar. 23 Grafik Pembandingan pada T5

Dapat dilihat dari pembandingan hasil pencatatan data pada suhu ruang secara grafik pada Gambar. 19 sampai dengan Gambar. 23 hasil pembacaan suhu pada modul masih fluktuatif namun modul dapat melakukan pembacaan suhu dengan kesalahan yang tidak lebih dari standart toleransi yaitu tidak lebih dari $10 \%$.

Dari pengambilan data yang peneliti lakukan. Letak peletakan sensor ukur yang sedikit berjarak antara sensor alat dan sensor pembanding pada saat pengukuran memungkinkan untuk menyebabkan perbedaan pembacaan suhu antara alat dengan pembanding atau dapat pula dikarenakan pemerataan suhu panas dalam ruangan yang kurang merata.

\section{7) Error Pembacaan Suhu}

Validasi nilai pembacaan suhu ditunjukkan dengan membandingkan hasil tampilan LCD pada modul dengan alat pembanding. Kesalahan pembacaan ditunjukkan pada Tabel I sebagai berikut:

TABLE I. ERROR PENGUKURAN ANTARA MODUL DENGAN ALAT PEMBANDING

\begin{tabular}{|c|c|c|}
\hline Suhu & Channel & Error (\%) \\
\hline $30{ }^{\circ} \mathrm{C}$ & 1 & $2.6 \%$ \\
\cline { 2 - 3 } & 2 & $4 \%$ \\
\hline
\end{tabular}

\begin{tabular}{|c|c|c|}
\hline \multirow{2}{*}{} & 3 & $4 \%$ \\
\cline { 2 - 3 } & 4 & $2.7 \%$ \\
\cline { 2 - 3 } & 5 & $3.2 \%$ \\
\hline \multirow{2}{*}{$100^{\circ} \mathrm{C}$} & 1 & $0.5 \%$ \\
\cline { 2 - 3 } & 2 & $0.8 \%$ \\
\cline { 2 - 3 } & 3 & $0,6 \%$ \\
\cline { 2 - 3 } & 4 & $0.1 \%$ \\
\cline { 2 - 3 } & 5 & $0.2 \%$ \\
\hline
\end{tabular}

Dari hasil pengukuran didapatkan nilai error terkecil $0.1 \%$ pada T4 saat pengukuran suhu uap air $\left(100^{\circ} \mathrm{C}\right)$ dan error terbesar 4\% pada T2 dan T3 saat pengukuran suhu ruang $\left(30^{\circ} \mathrm{C}\right)$.

\section{DISKUSI}

Seperti penelitian sejenis sebelumnya dalam studi literatur kali ini peneliti menggunakan sensor thermocouple tipe-K. Dalam pengamatan beberapa grafik pembandingan hasil pencatatan pada modul terhadap alat pembanding ditemukan bahwa hasil pembacaan modul mendekati pembacaan pembanding membuktikan bahwa sensor thermocouple tipe-K memiliki respon pembacaan yang cepat dan baik[5]. Namun pembacaan pada modul masih fluktuatif dibanding alat pembanding. Berdasarkan tabel error pengukuran modul terhadap perangkat pembanding pada Tabel I. menunjukkan nilai error terbesar pada saat pengukuran suhu ruang sebesar $4 \%$ dan pada saat pengukuran suhu uap air sebesar $0.8 \%$ masih dalam kisaran standart toleransi tidak lebih dari $10 \%$. Alat yang peneliti buat merupakan pengembangan dari penelitianpenelitian sebelumnya yang belum dapat menampilkan hasil data kedalam bentuk grafik. Dengan melakukan pengembangan sistem pemantauan grafik seperti pada studi literatur dengan menggunakan PLX-DAQ, peneliti dapat memploting grafik hasil pengukuran secara realtime pada lembar Microsoft Excel [11][12]. Namun pada pembuatan alat tampilan grafik belum sempurna masih dalam parameter suhu banding kolom data yang diterima, sehingga pemantauan waktu terjadinya pengukuran sementara dapat dilihat secara manual pada kolom Direct Debug pada aplikasi PLX-DAQ. Dalam pengiriman data serial hasil pembacaan modul menggunakan Bluetooth HC-05 dapat diakses secara nirkabel, namun hanya dapat terhubung hingga jarak tertentu. Untuk itu penggunaan pemantauan dengan komputer sebaiknya dilakukan berdekatan dengan modul. Dilihat dari pembacaan modul dibandingkan dengan alat pembanding masih ditemukan perbedaan pembacaan yang berbeda kemungkinan disebabkan oleh beberapa faktor yaitu pendistribusian suhu tidak merata dari sumber panas dan karena adanya jarak pada peletakan sensor modul dengan sensor pembanding. 


\section{KESIMPULAN}

Tujuan dari penelitian ini untuk memudahkan pemantauan kinerja alat dalam pendistribusian suhu secara grafik dengan 5 titik pengukuran pada saat dilakukan kalibrasi sehingga dapat memudahkan mengevaluasi siklus suhu pada sterilisator. Penelitian ini telah membuktikan bahwa dapat dibuatnya alat Kalibrator Suhu dengan Thermocouple Dilengkapi dengan Tampilan Grafik menghasilkan keakuratan pembacaan yang baik dengan menggunakan sensor thermocouple tipe-K dan dapat melakukan pemantauan siklus suhu dalam bentuk grafik pada Microsoft Excel secara realtime. Penelitian lebih lanjut diperlukan untuk mengatasi pembacaan yang masih fluktuatif. Dikembangkan agar modul dapat melakukan pembacaan suhu dengan kesalahan pembacaan data yang lebih kecil. Pada tampilan grafik pemantauan perlu dilakukan penyempurnaan dengan menambahkan waktu pengukuran.

\section{DAFTAR PUSTAKA}

[1] E. M. DARMADY, K. E. HUGHES, J. D. JONES, D. PRINCE, and W. TUKE, "Sterilization by dry heat.," $J$. Clin. Pathol., vol. 14, pp. 38-44, 1961, doi: 10.1136/jcp.14.1.38.

[2] P. E. S. Richman, "METHOD AND APPARATUS FOR SURFACE STERILIZATION," no. 19, 1973.

[3] G. Havrilla, "Troubleshooting Steam Sterilization Process Failures," Infect. Control, no. October, 2005.

[4] L. Dhar, "VALIDATION OF DRY HEAT STERILIZATION METHODS | PharmaTutor.”.

[5] M. Sofyan, A. Pudji, and Syaifuddin, "Alat Kalibrasi Suhu dengan Thermocouple dilengkapi Thermohygrometer," pp. 1-8, 2016.

[6] “AS 2853-1986 Enclosures - Temperature-controlled Performance testing and grading. New South Wales: STANDARDS AUSTRALIA (STANDARDS ASSOCIATION OF AUSTRALIA)."

[7] A. Bintari, "Kalibrator Suhu dengan Thermocouple dan Thermohygrometer Dilengkapi Penyimpanan Data," no. 2013, pp. 0-5, 2017.

[8] S. Naufal Syayakti and E. Dian Setioningsih, "Indonesian Journal of Electronics, Electromedical, and Medical Informatics (IJEEEMI) 644 Channel Sterilizer Calibrator," Ijeemi, vol. 1, no. 2, pp. 65-70, 2019, doi: 10.35882/ijeeemi.v1i2.4.

[9] A. Z. Febriyanti and P. C. Nugraha, "Temperature Calibrator Using Thermocouple Based on Microcontroller," vol. 2, no. 1, pp. 13-20, 2020, doi: 10.35882/ijeeemi.v2i1.3.

[10] Rizkiyatussani, Her Gumiwang Ariswati, and Syaifudin, "Five Channel Temperature Calibrator Using Thermocouple Sensors Equipped With Data
Storage," J. Electron. Electromed. Eng. Med. Informatics, vol. 1, no. 1, pp. 1-5, 2019, doi: 10.35882/jeeemi.v1il.1.

[11] M. R. Fachri, I. D. Sara, and Y. Away, "Pemantauan Parameter Panel Surya Berbasis Arduino secara Real Time," J. Rekayasa Elektr., vol. 11, no. 4, p. 123, 2015, doi: 10.17529/jre.v11i3.2356.

[12] A. El Hammoumi, S. Motahhir, A. Chalh, A. El Ghzizal, and A. Derouich, "Low - cost virtual instrumentation of PV panel characteristics using Excel and Arduino in comparison with traditional instrumentation," Renewables Wind. Water, Sol., 2018, doi: 10.1186/s40807-018-0049-0.

[13] Maxim Integrated, "MAX6675 Datasheet," p. 8, 2014, [Online]. Available: www.maximintegrated.com.

[14] M. S. Mukhlis and A. R. Machdi, "Oleh :," Sist. MIKROKONTROLER ATMEGA328 SEBAGAI PENGONTROL SUHU DAN Lev. AIR, no. Lcd, pp. 1$10,2015$. 